PROSIDING XXVII DAN KONGRES X PERHAPI 2018

\title{
PENERAPAN KONSEP ZERO FUEL BURN DENGAN OPTIMALISASI DESAIN JALAN HAULING DALAM RANGKA EFISIENSI PENGGUNAAN FUEL
}

"ADVANCED ZERO FUEL BURN"

Budi Santoso, Arruya Ashadiqa, Safaruddin, Tomi Indrianto, Hisham

\section{PT. SAGO PRIMA PRATAMA (J Resources) Site Seruyung}

\begin{abstract}
ABSTRAK
Advanced Zero Fuel Burn merupakan program khusus yang di peruntukkan untuk efisiensi pemakaian bahan bakar pada unit hauler khususnya unit OHT 773 CAT, dengan mengoptimalkan beberapa fitur record data yang dimiliki oleh sistem electronic menggunakan fasilitas ET Tool Downloader Caterpillar, sehingga didapatkan data record dan graphic pemakaian bahan bakar selama unit dioperasikan.

Data tersebut di evaluasi dan di entrepetasikan, bahwa ketika unit hauler OHT 773 CAT dioperasikan dalam kondisi bermuatan bisa tercapai ZERO pembakaran bahan bakar di jalan turunan (Downhill) dengan konsisten mengaplikasikan zero throtle, aktif retarder, penyesuaian speed dan gear pada grade road 10-12\%.

Program ini merupakan tindak lanjut dari hasil report SAT Desember 2017 yang dilakukan oleh Tim Trakindo Utama di Site Seruyung pertambangan emas PT Sago Prima Pratama, di mana secara data diperoleh kategori rate fuel consumption unit OHT773 yang dapat dioptimalkan menjadi lebih efisien dan selanjutnya PT Sago Prima Pratama mengembangkan informasi ini menjadi program khusus untuk mendapatkan pengoperasionalan unit OHT yang lebih ekonomis, produktif dan tentunya tetap memperhatikan aspek safety.

Pelaksanaan program studi zero fuel burn juga melibatkan pihak Trakindo Utama sebagai pembimbing di kelas dan dilapangan.

Kata-kata kunci: Zero fuel burn, OHT773E, downhill, zero throtle \& grade road 10$12 \%$.
\end{abstract}




\section{LATAR BELAKANG}

Program Advanced Zero Fuel Burn merupakan salah satu program yang di buat untuk pemenuhan Objektif Target Program (OTP) perusahaan yaitu melakukan efisiensi penggunaan bahan bakar solar untuk operasional unit hauler OHT 773 sebanyak 3\% dari pemakaian bahan bakar pada tahun 2017 dengan memanfaatkan opportunity design jalan tambang yang ada.

Selanjutnya dalam upaya pemenuhan Peraturan Pemerintah No. 70 Tahun 2009 tentang "Konservasi Energi" pasal 12 ayat 1 yaitu pemanfaatan energi oleh pengguna sumber energi dan pengguna energi wajib dilakukan secara hemat dan efisien.

\section{TUJUAN STUDI}

1. Untuk membuat desain jalan hauling terutama terkait dengan grade jalan yang optimum sehingga konsep zero fuel burn dapat diterapkan dengan baik pada unit OHT 773.

2. Untuk menghitung efisiensi penggunaan bahan bakar dengan cara pengambilan data logger unit OHT 773 dengan melakukan perbandingan base line (1) dan Zero Line (2).

3. Untuk menghitung besarnya peningkatan produktivitas unit OHT ketika menerapkan konsep zero fuel burn.

Untuk menghitung besarnya penurunan down time hours khususnya pada bagian tyre dan

\section{DASAR TEORI / KONSEPTUAL STUDI 3.1_Desain Jalan Hauling}

Kemiringan jalan berhubungan langsung dengan kemampuan hauler baik dalam pengereman maupun dalam mengatasi tanjakan. Kemiringan jalan pada umumnya dinyatakan dalam persen (\%). Kemiringan jalan maksimum yang dapat dilalui dengan baik oleh hauler berkisar antara 10\%-15\%, tergantung pada jenis alatnya. Pada studi ini, grade jalan yang digunakan sekitar 9-10\%. Sedangkan untuk lebar jalan yang digunakan yaitu disesuaikan dengan lebar unit terbesar yang lewat yaitu OHT 773 yang memiliki lebar sekitar 5.1 meter maka lebar jalan yang digunakan yaitu 3.5 x $5.1=18$ meter (belum termasuk parit dan tanggul pembatas).

\section{2_Brake Performance Curve}


Gear dan kecepatan dari hauler harus disesuaikan ketika melewati suatu jalan turunan (downhill) dengan mengaktifkan auto retarder, tujuannya agar didapatkan kecepatan yang optimal sehingga hauler tidak perlu mengganti gear atau melakukan pengereman yang dapat menimbulkan pembakaran fuel pada saat melewati jalur tersebut. Gear dan kecepatan tersebut dapat diperoleh dari kurva Brake Performance OHT 773E, di mana untuk mendapatkan kedua nilai tersebut kita membutuhkan data gross machine weight dan total effective grade di sepanjang jalur turunan (downhill) tersebut. Berikut merupakan grafik Brake Performance OHT 773E.

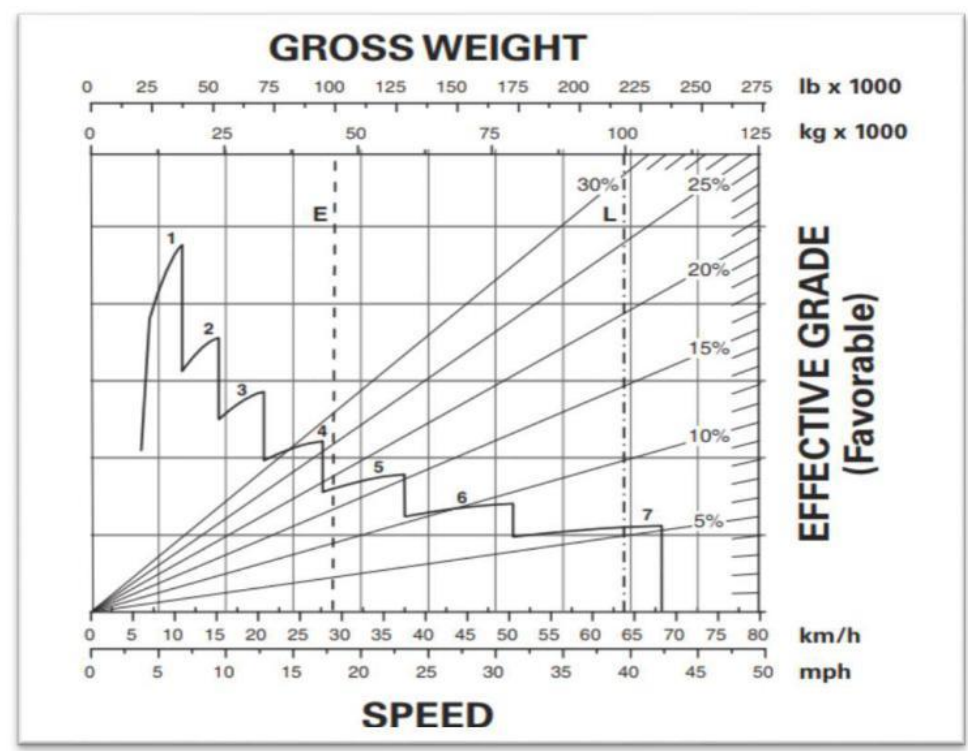

Gambar 3. Brake Performance Curve OHT 773E

\section{3_Zero Fuel Burn Concept}

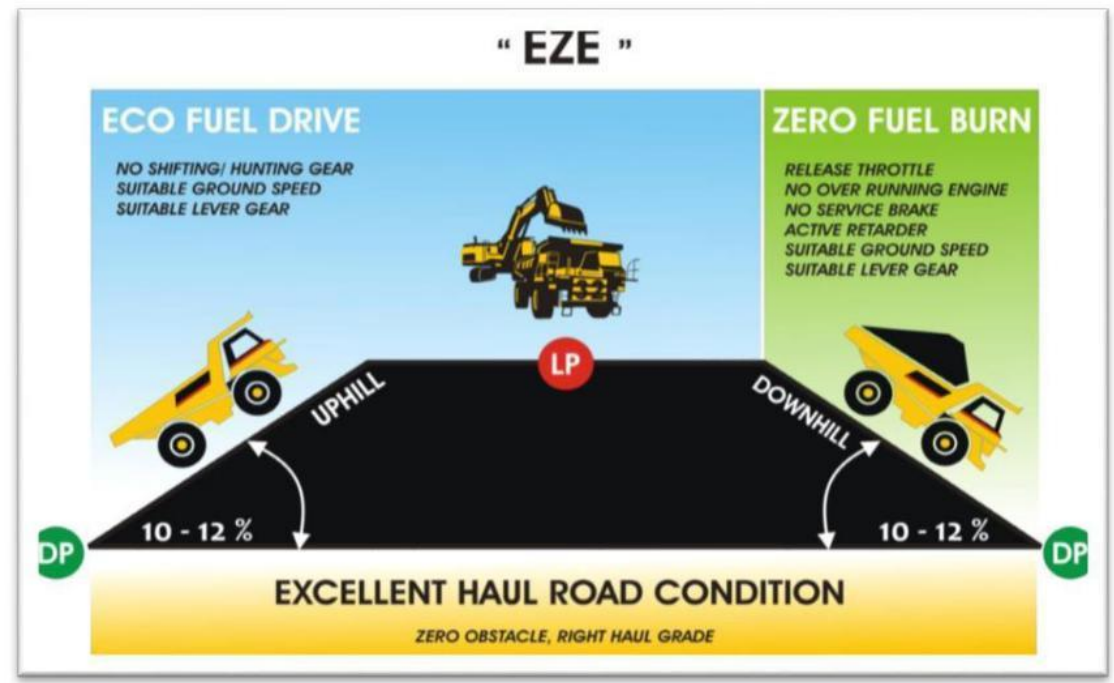

Gambar 4. Konseptual Studi EZE 


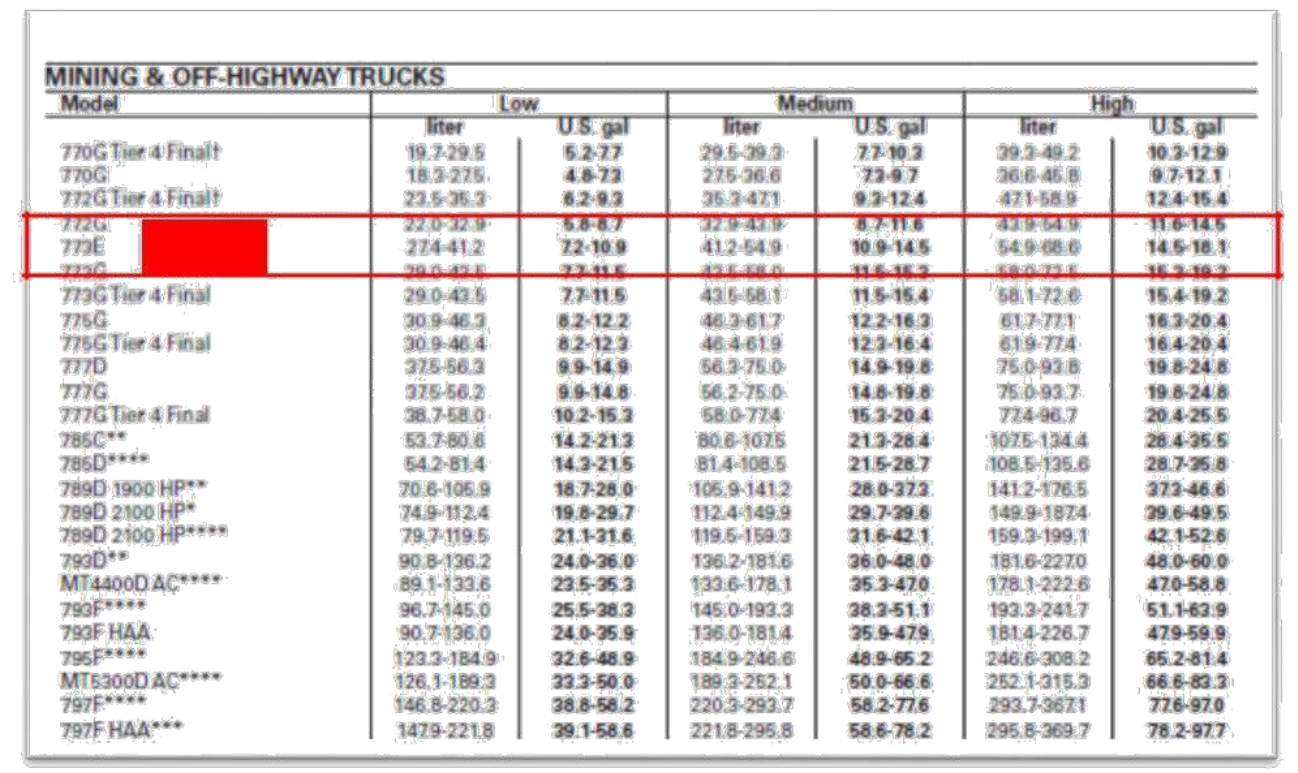

Tabel 1. Fuel Consumption unit OHT

\section{4_Produktivitas Hauler}

Produktivitas hauler adalah kemampuan hauler untuk memindahkan material per satuan waktu yang dinyatakan dalam ton/jam. Untuk mencari produktivitas dari hauler, dapat menggunakan rumus berikut.

$$
\mathbf{P}=\quad \frac{\text { H.BD }}{\mathrm{C}}
$$

\section{Keterangan}

$\mathrm{P}$

$\mathrm{H}$

BD

$\mathrm{C}$
: Produktivitas (ton/jam)

: Vessel capacity (bcm)

: Bulk density (ton/bcm)

: Cycle time (detik dikonversi

menjadi jam)

Pengertian cycle time pada dasarnya sama untuk semua alat berat, yang membedakan hanya siklusnya.

Untuk cycle time hauler, siklusnya terdiri dari waktu spotting, loading, hauling, dumping dan return

hauling. Cycle time diukur dalam satuan detik berdasarkan perhitungan langsung di lapangan.

\section{5_Physical Availability}

Physical Availability (PA) adalah persentase ketersediaan unit untuk digunakan tanpa terganggu oleh kerusakan atau perbaikan baik secara terencana (Schedule 
Maintenance) maupun tidak terencana (Unschedule Maintenance). Kerusakan di dalamnya juga bisa termasuk kerusakan non technical seperti misalnya unit rusak dikarenakan terjadinya accident ini juga akan mempengaruhi ketersediaan alat secara fisik. Berikut merupakan rumus untuk menghitung PA dari suatu unit :

$$
\text { MOHH - BD }
$$

\section{PA $(\%)=\overline{\mathrm{MOHH}} \times \mathrm{x} 100 \%$}

\section{Keterangan :}

PA

MOHH (MJ) : Man On Hand Hours (jam)

BD : Breakdown Hours (jam)

\section{METODE STUDI}

\section{1_Penggunaan Aplikasi Software}

\begin{tabular}{|l|l|}
\hline SURPAC & Pembuatan desain jalan hauling dengan menggunakan software surpac. \\
\hline ET Tool CAT & $\begin{array}{l}\text { Pengambilan data primer berupa data logger yang diperlukan dengan } \\
\text { menggunakan kabel ET Com Adapter dan software ET Tool Caterpillar. } \\
\text { Sistem } \\
\text { download adalah real time yaitu dilakukan selama unit sedang beroperasi } \\
\text { Selama } \\
1 \text { jam. }\end{array}$ \\
Gambar 5. Aktivitas pengecekan data pasca download
\end{tabular}

\section{2_Pemilihan/seleksi Data logger yang diperlukan}


Sebelum melakukan aktivitas download maka seorang downloader harus melakukan pemilihan parameter yang hanya dibutuhkan dalam studi sebagai berikut ini :

1. Body Up

2. Gear

3. Level Gear

4. Ground Speed

5. $\quad$ ARC Control Selenoid

6. Auto Retarder

$7 . \quad$ Retarder

8. Service Brake

9. $\quad$ Engine Speed

10. Fuel Consumption

11. Throttle Position

\section{3_Alat studi dan Unit Hauler}

a. ET Tool Downloader

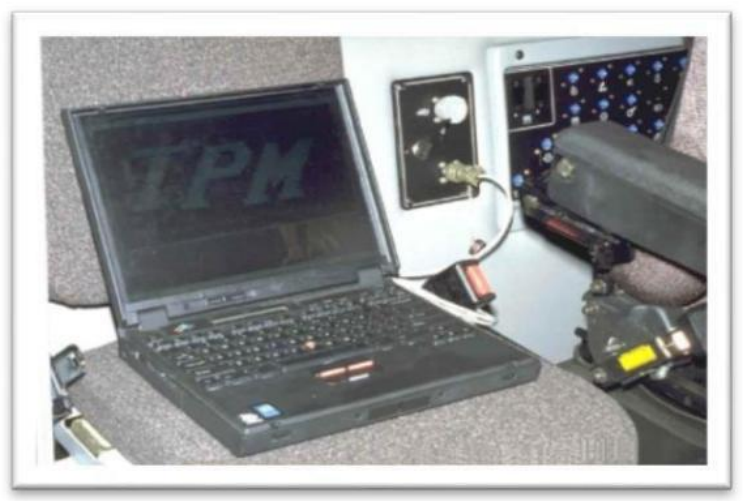

Gambar 6. Instalasi ET tool di kabin unit OHT 773

\section{b. Unit OHT 773E}
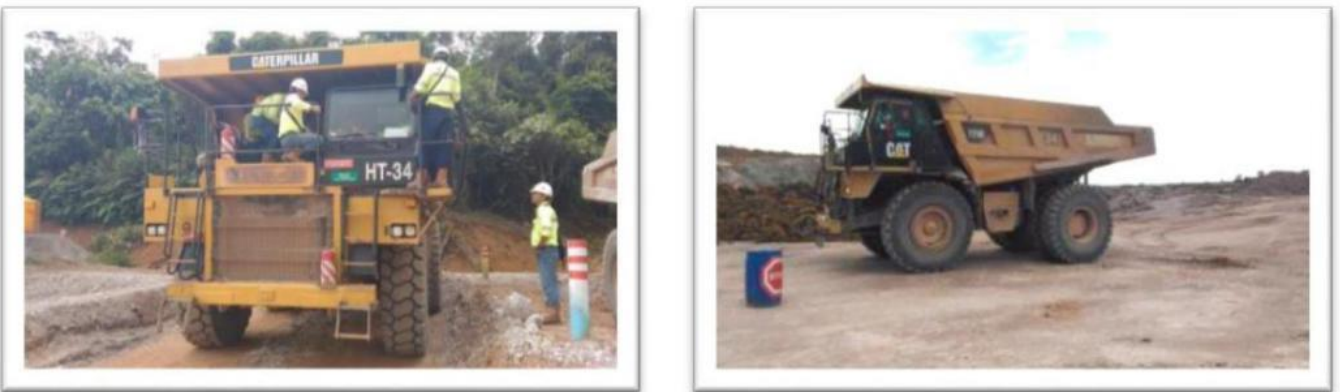

Gambar 7. Aktivitas persiapan unit OHT 773 


\section{c. Alat pendukung}

Alat pendukung yang dibutuhkan ketika proses download data loger dilakukan adalah : - Stopwatch

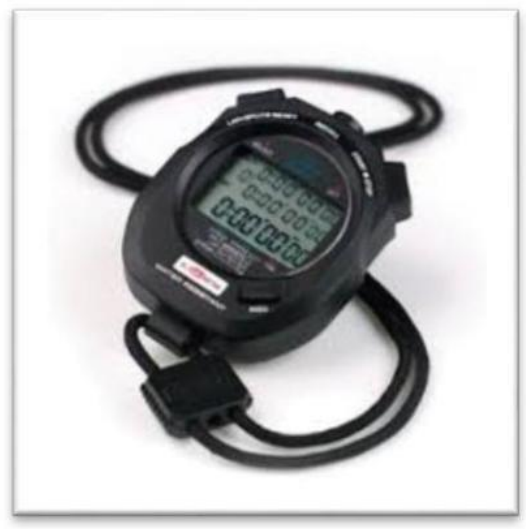

\section{Gambar 8. Contoh penggunaan alat ukur waktu.}

- $\quad$ Form Pengambilan Data

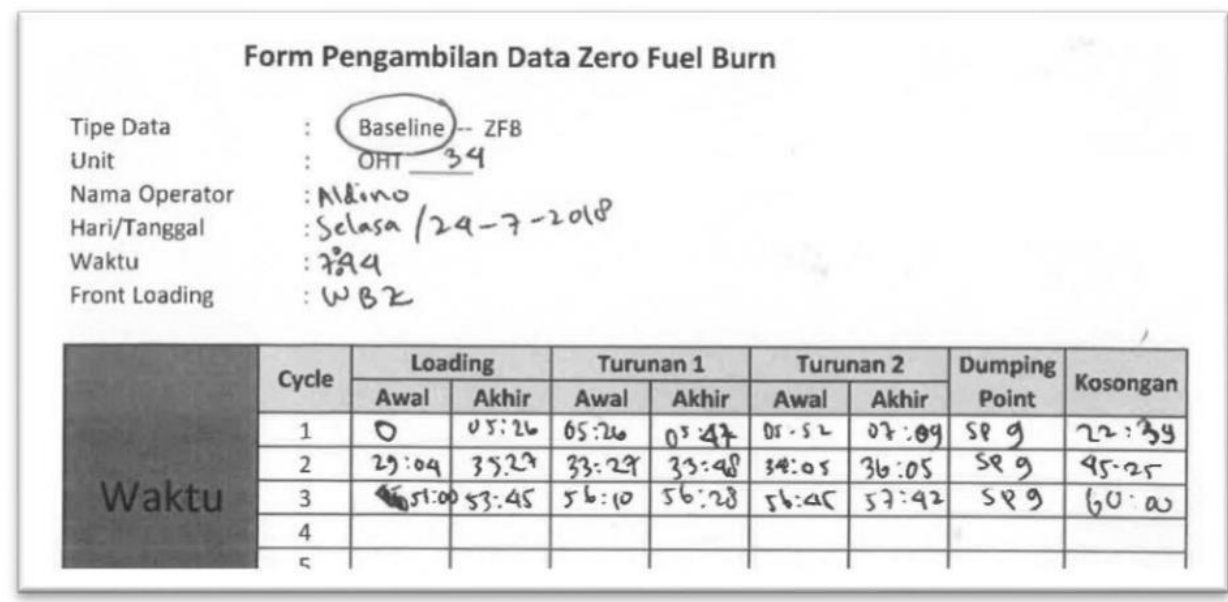

Gambar 9. Contoh pengisian form data download

Kedua peralatan di atas dibutuhkan untuk melakukan pencatatan waktu berlangsungnya even - even tertentu yang dikalibrasikan dengan data loging, sehingga ke akuratan data semakin optimal, beberapa even yang dimaksud sbbi :

- $\quad$ Loading point

- $\quad$ Dumping Point

- $\quad$ Masuk turunan zero line

- $\quad$ Obstacle (Adanya unit WT, Grader, LV dll).

\section{4_Aplikasi jalur Zero Line}

Diaplikasikan ketika unit melakukan travel di turunan/downhill tanpa menginjak throttle dg lever gear, ground speed dan grade jalan yang sesuai (Tepat) sehingga 
unit turun dengan optimal tanpa terjadi over running pada engine dan tidak ada hambatan.

\section{4_Efisiensi Bahan Bakar}

1. Untuk menghitung efisiensi bahan bakar maka pengambilan data loger dilakukan 2 kali yaitu untuk base line(1) dan Zero line (2).

2. Melakukan perbandingan data loger base line vs data loger zero. Pegambilan data logger dilakukan selama satu jam atau dapat ditentukan dalam hitungan 1 cycle $(1$ Cycle = Loading Point to Loading Point atau Dumping Point to Dumping Point) pada satu unit OHT.

3. Pengambilan data cycle time aktual unit OHT dengan menyamakan kondisi di loading point dan dumping point sehingga variabel bebasnya ada di jalur zero fuel burn.

4. Data zero fuel burn diperoleh dari data record dan grafik yang menunjukkan trend di angka nol/zero, seperti ilustrasi berikut ini :

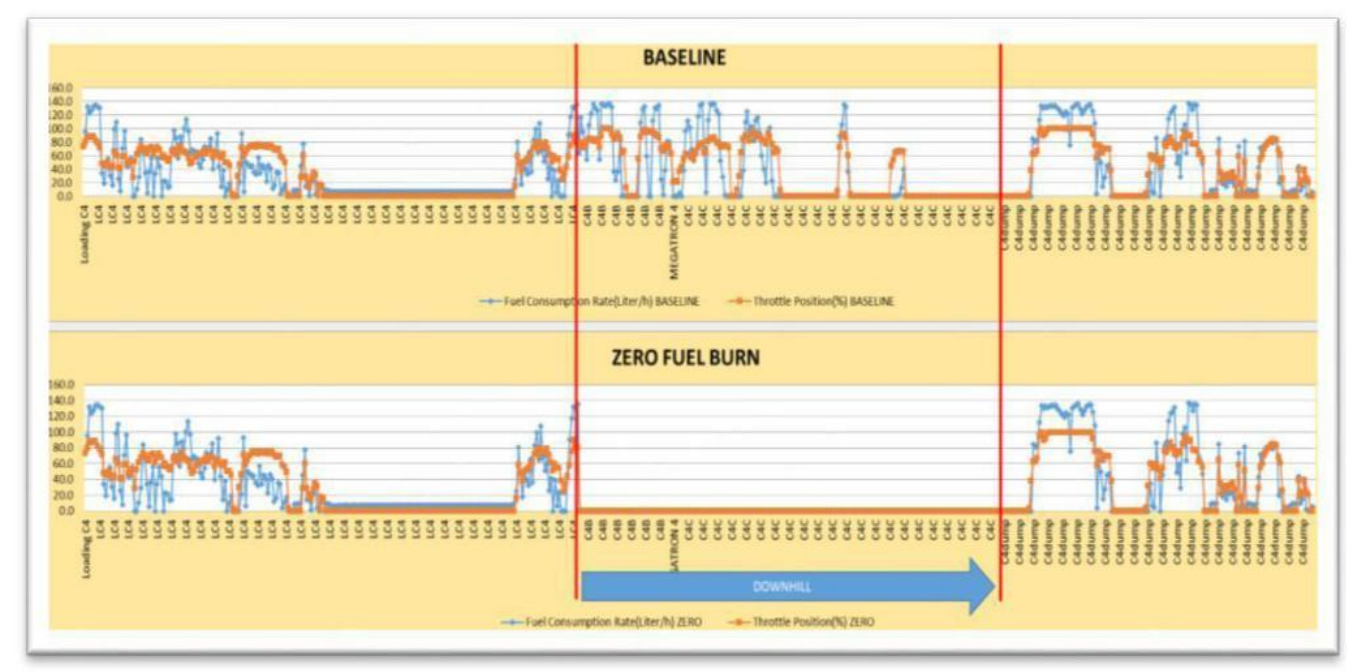

Gambar 10. Ilustrasi Zero Fuel Burn

\section{5_Mine Engineering}

- $\quad$ Menghitung time cycle operasional unit OHT 773E.

- $\quad$ Mengumpulkan data down time tyre dan suspense unit OHT 773E.

\section{PENGUMPULAN DATA}

\section{1_Desain Jalan Hauling}


Dengan menggunakan software Surpac, dibuatlah desain final jalan hauling di

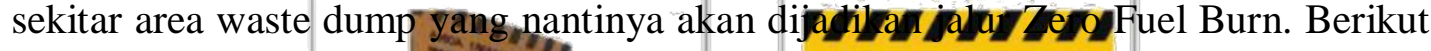

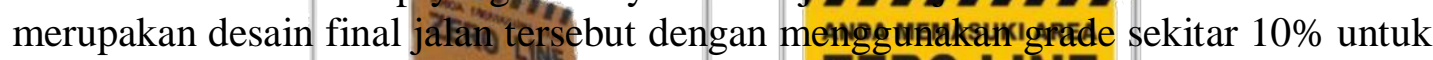

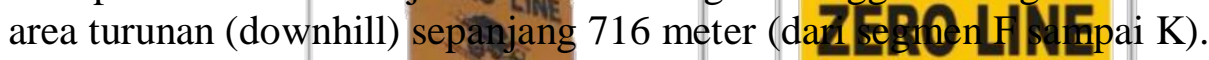

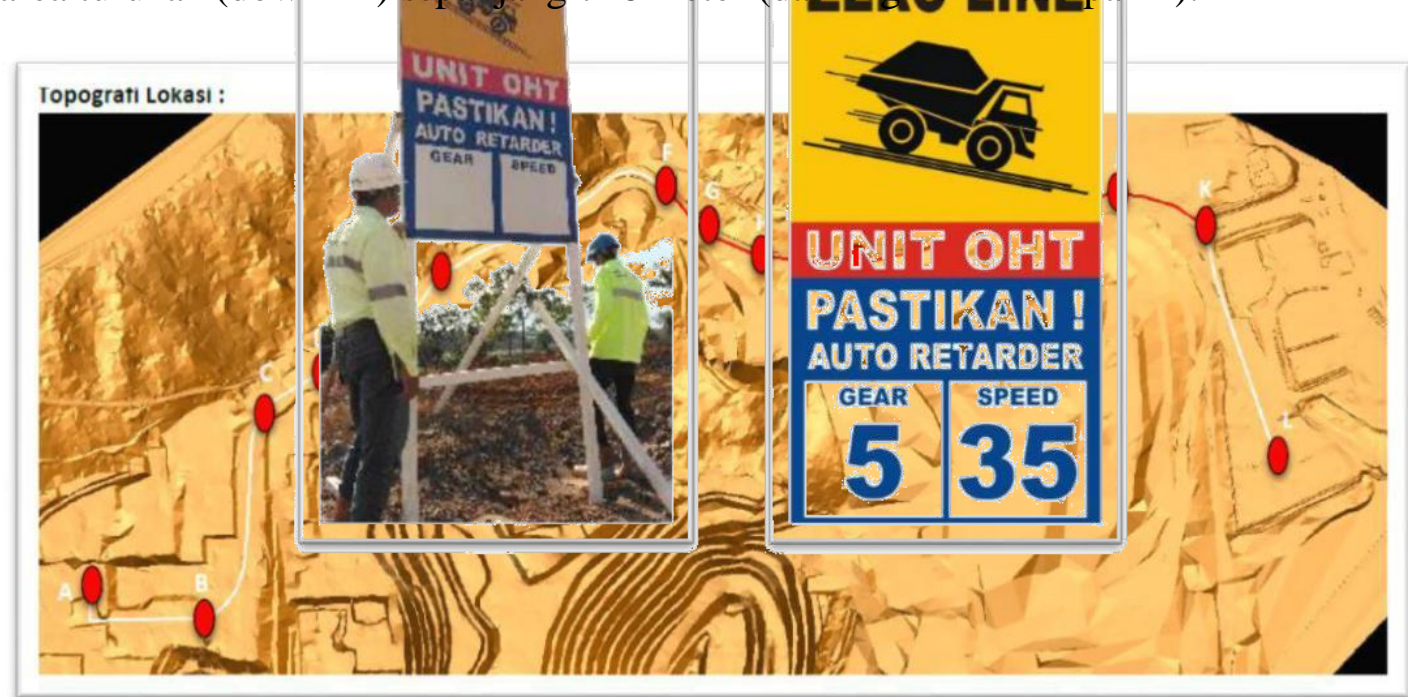

Gambar 11. Jalur Hauling Di Lihat Dari Peta (Tampak Atas)

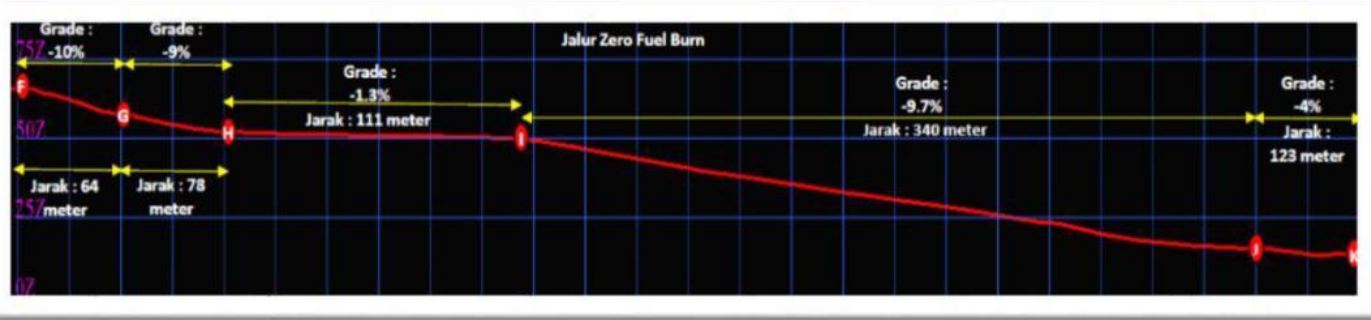

Gambar 12. Cross Section Jalur Zero Fuel Burn (Segmen F-K)

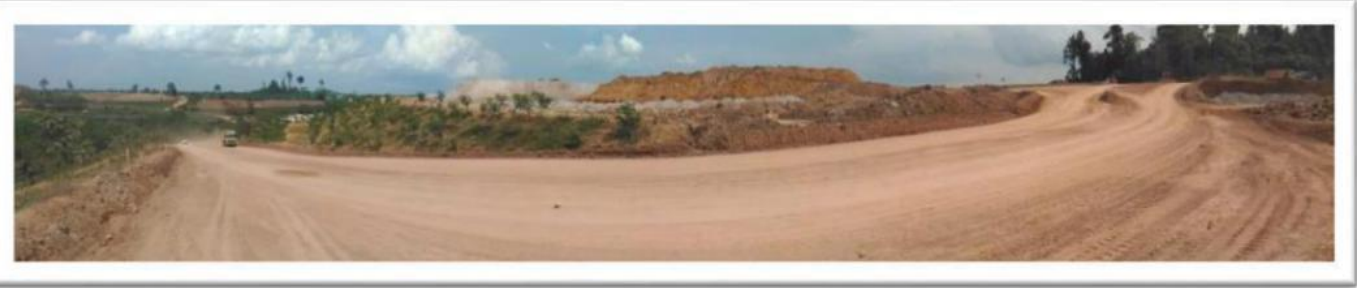

Gambar 13. Konstruksi Zero Line 


\section{Gambar 14. Pemasangan Rambu Zero}

\section{Line 5.2_Rekomendasi Gear dan Ground Speed}

Untuk menentukan gear dan kecepatan yang harus digunakan oleh operator hauler, dapat menggunakan 2 cara yaitu :

a. Menggunakan kurva Brake Performance OHT 773E yang terdapat di handbook product Caterpillar. Data yang dibutuhkan yaitu gross weight dari OHT (berat kosongan+muatan) dan effective grade di sepanjang jalur Zero Fuel Burn. Berat kosongan dari OHT 773E yaitu 40 ton dan berat muatan yang ditargetkan yaitu 55 ton sehingga gross weight dari OHT 773E menjadi 95 ton. Untuk total effective grade di sepanjang jalur Zero Fuel Burn yaitu sekitar $10 \%$.

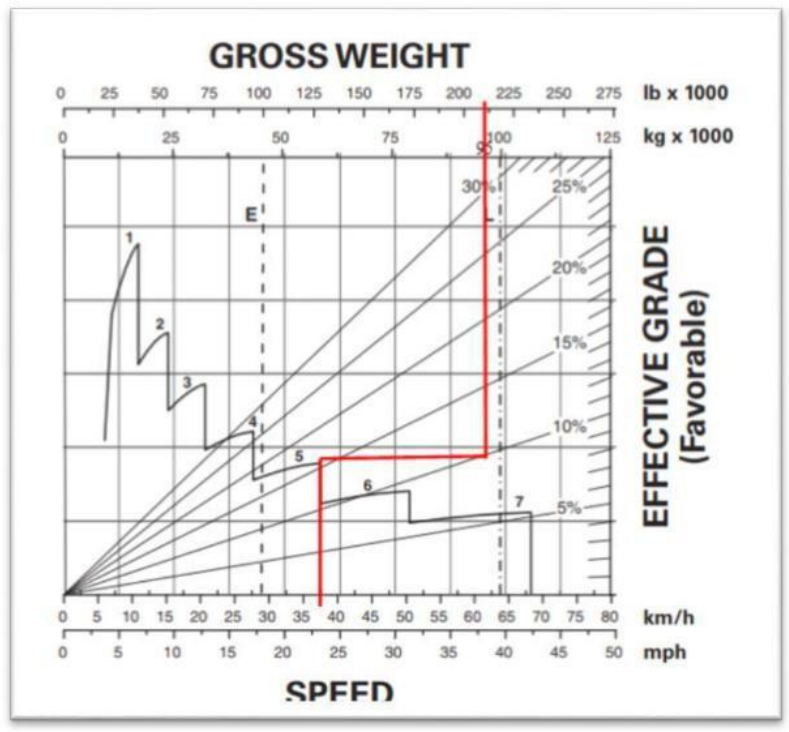

Tabel 2. Brake Performance Curve OHT 773E 
b. Menggunakan download data loger Zero Line, yang digunakan sebagai data base melakukan tuning gear dan speed.

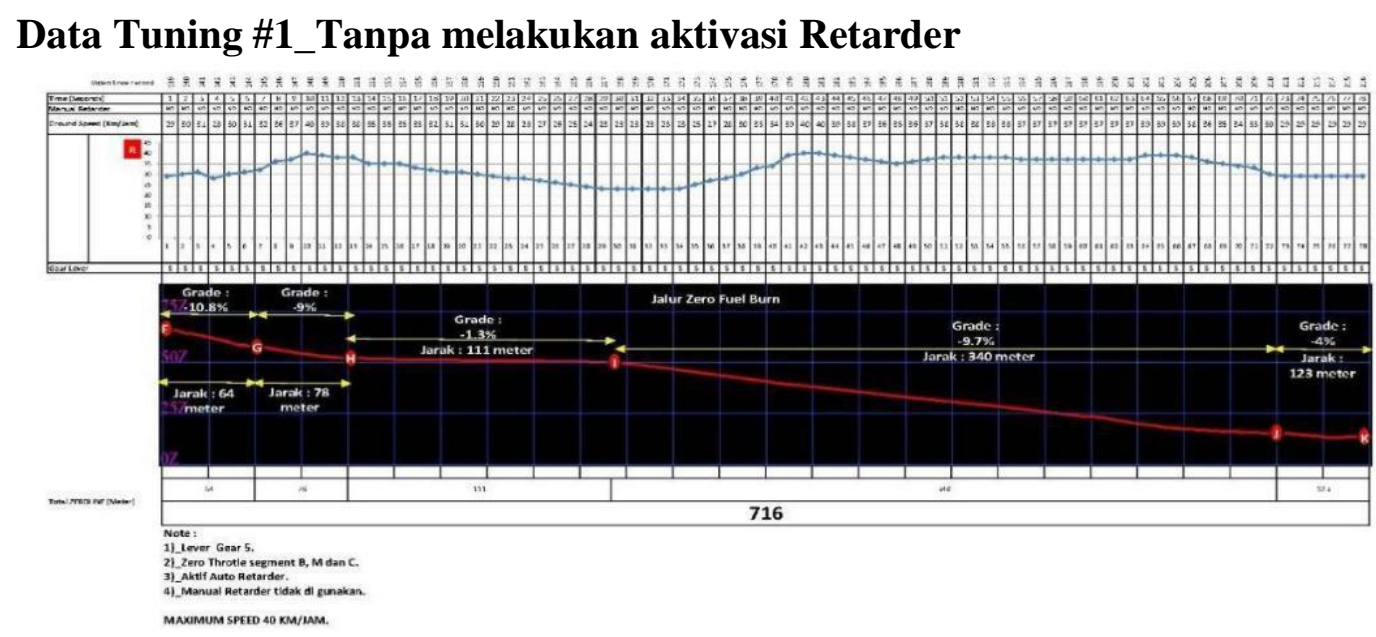

Data Tuning \#2_Melakukan aktivasi Retarder

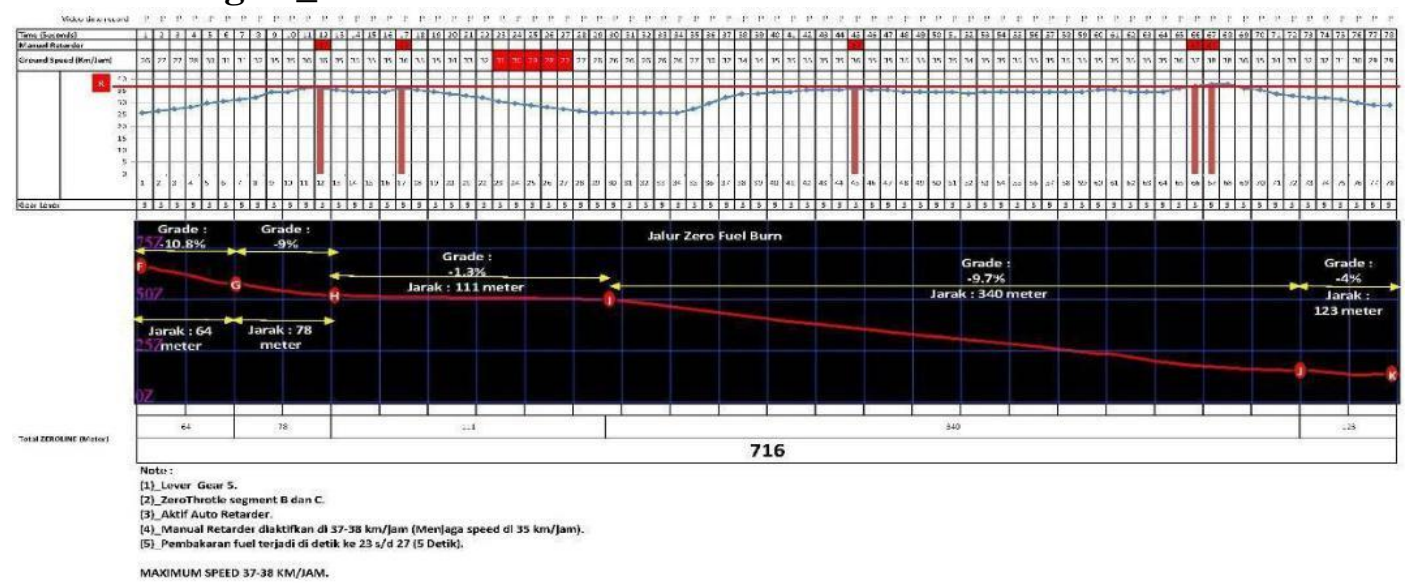

Gambar 15. Data tuning Gear \& Speed jalur Zero Line

Berdasarkan kurva brake performance dan hasil data tuning di atas, dapat dilihat bahwa gear yang disarankan yaitu gear 5 dan kecepatan maksimum ada di range 37-38 km/jam. Namun untuk penerapannya di maksimalkan kecepatan maksimum adalah $35 \mathrm{~km} / \mathrm{jam}$.

\section{3_Pelatihan dan seting ke operator Hauler}

Gear dan kecepatan yang direkomendasikan tersebut selanjutnya disosialisasikan ke semua operator OHT 773E melalui training dan pengarahan di lapangan. 

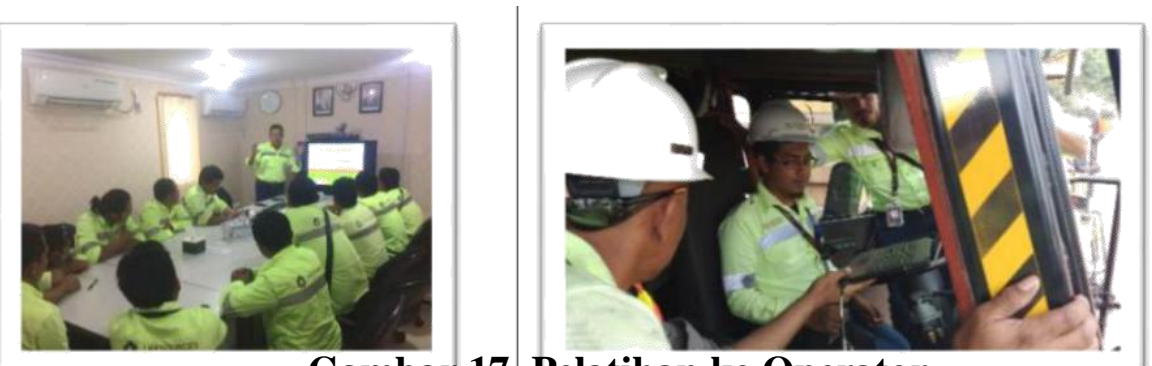

Gambar 17. Pelatihan ke Operator

\section{4_Data Fuel Consumption}

Untuk mendapatkan perhitungan efisiensi fuel maka harus dilakukan download data loger secara real time yang dikontrol oleh seorang downloader yang sudah mendapatkan pelatihan.

Berdasarkan pengambilan data di lapangan di peroleh grafik baseline dan zero line, sebagai referensi dalam melakukan perhitungan efisiensi fuel.

\section{a. Pengambilan data loger base line.}

Salah satu contoh profil data loger base line unit OHT 773.

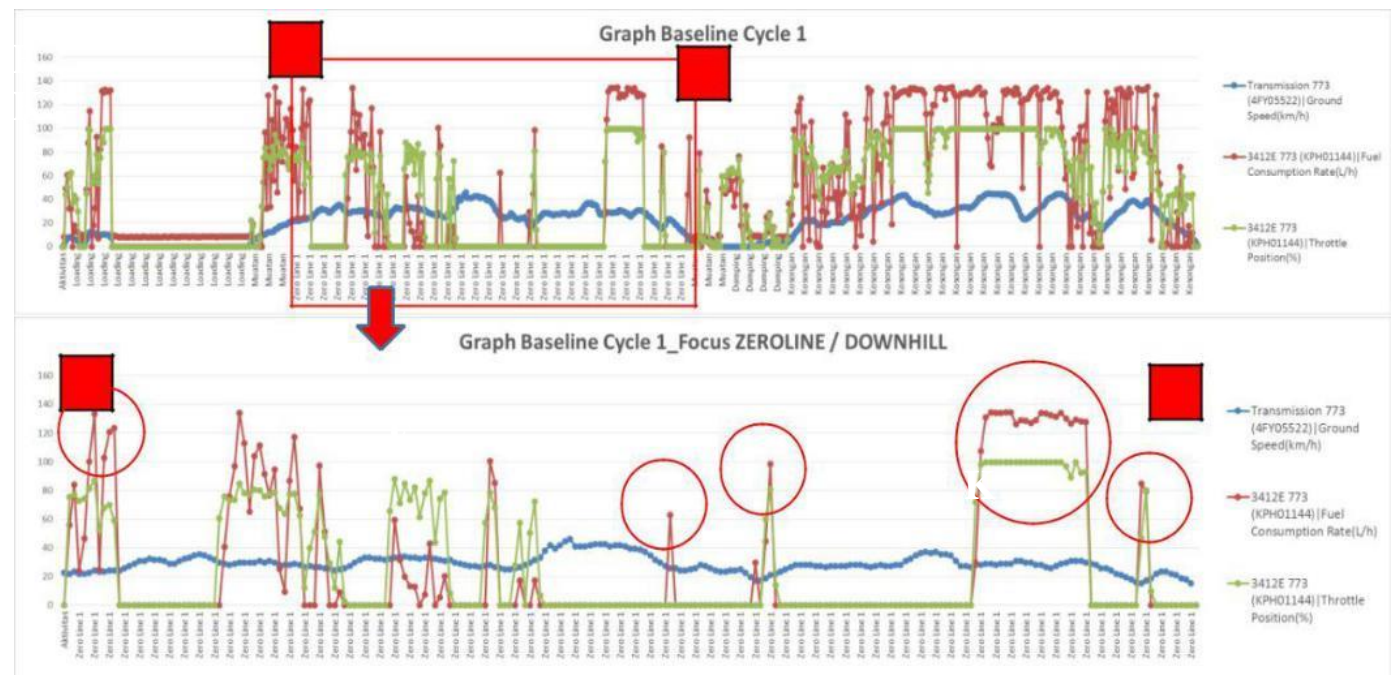

Grafik 1_Performa Baseline

Pada performa baseline menunjukkan banyak spike fuel di downhill (Zero line), spike-spike tersebut menjadi target untuk di ZERO kan dengan melakukan rekontruksi jalur downhill serta tuning gear \& ground speed.

\section{b. Pengambilan data loger zero line}

Event ini dilakukan setelah operator OHT CAT 773E di training oleh instruktur sesuai dengan rekomendasi data tuning, sehingga didapatkan hasil sebagai berikut : 


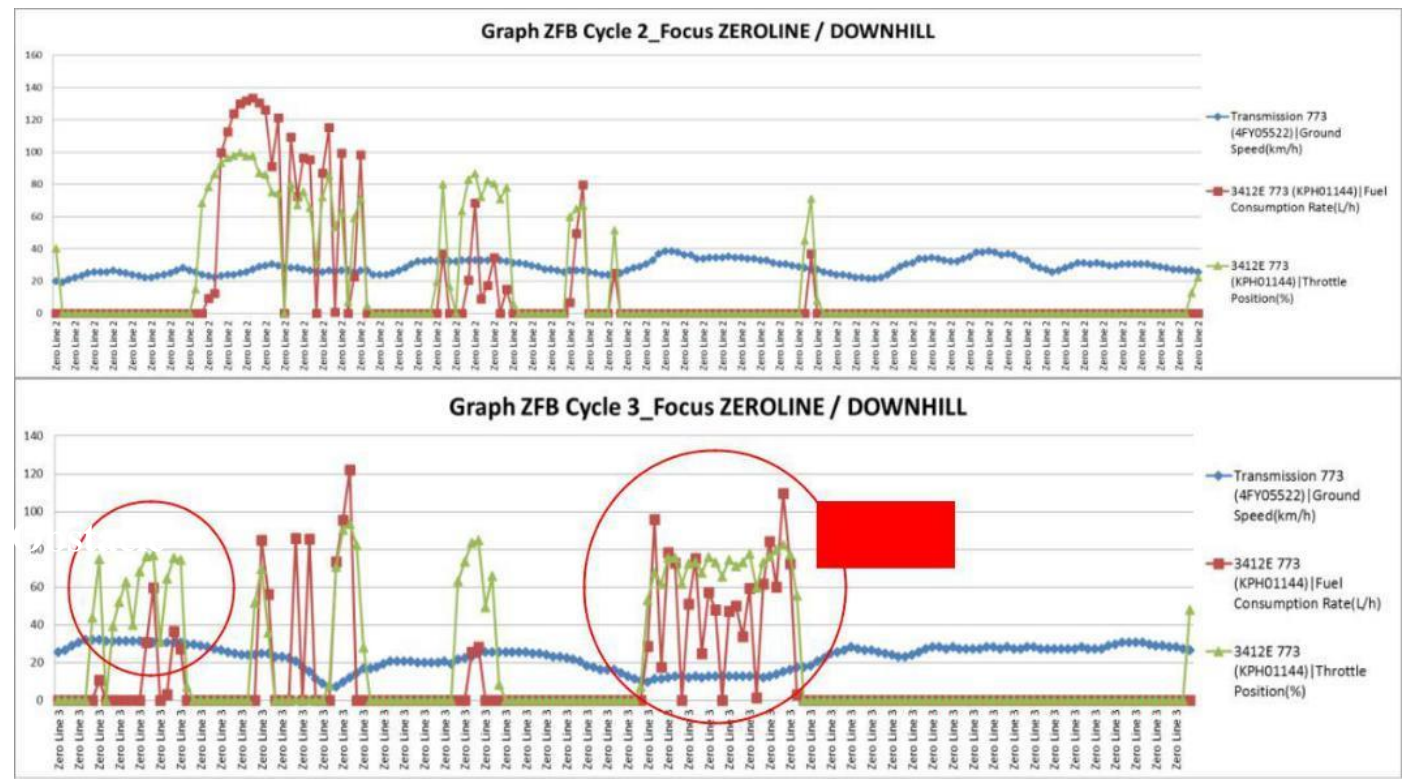

Grafik 2_Performa ZERO Line

Pada grafik ZFB cycle 2 menunjukkan performa zero fuel yang optimal, namun pada grafik ZFB cycle 3 terlihat ada beberapa spike di awal dan di pertengahan yang di akibatkan adanya obstacle (Water Truck beroperasi).

Perhitungan efisiensi fuel dilakukan dengan 2 pendekatan yang berbeda sbb :

\section{a. Pendekatan Fuel Rate}

Dapat digunakan apabila data jumlah cycle untuk data base line dan zero line berbeda.

\begin{tabular}{|c|c|c|c|c|}
\hline \multicolumn{5}{|c|}{ BASELINE } \\
\hline Kategori & Cycle ke & Aktivitas & $\begin{array}{l}\text { Rate Fuel } \\
\text { Consumption } \\
\text { (Liter) }\end{array}$ & $\begin{array}{c}\% \text { tase } \\
\text { fuel burn }\end{array}$ \\
\hline \multirow{12}{*}{ 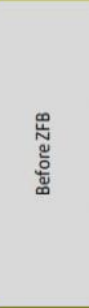 } & \multirow{4}{*}{ Cycle 1} & Loading & 20.10 & $12.91 \%$ \\
\hline & & Muatan & 29.56 & $19.00 \%$ \\
\hline & & Dumping & 26.60 & $17.09 \%$ \\
\hline & & Kosongan & 79.36 & $51.00 \%$ \\
\hline & \multirow{4}{*}{ Cycle 2} & Loading & 14.27 & $9.17 \%$ \\
\hline & & Muatan & 26.43 & $16.98 \%$ \\
\hline & & Dumping & 20.85 & $13.40 \%$ \\
\hline & & Kosongan & 82.95 & $53.30 \%$ \\
\hline & \multirow{4}{*}{ Cycle 3} & Loading & 11.08 & $7.12 \%$ \\
\hline & & Muatan & 31.12 & $20.00 \%$ \\
\hline & & Dumping & 22.08 & $14.19 \%$ \\
\hline & & Kosongan & 79.11 & $50.84 \%$ \\
\hline
\end{tabular}
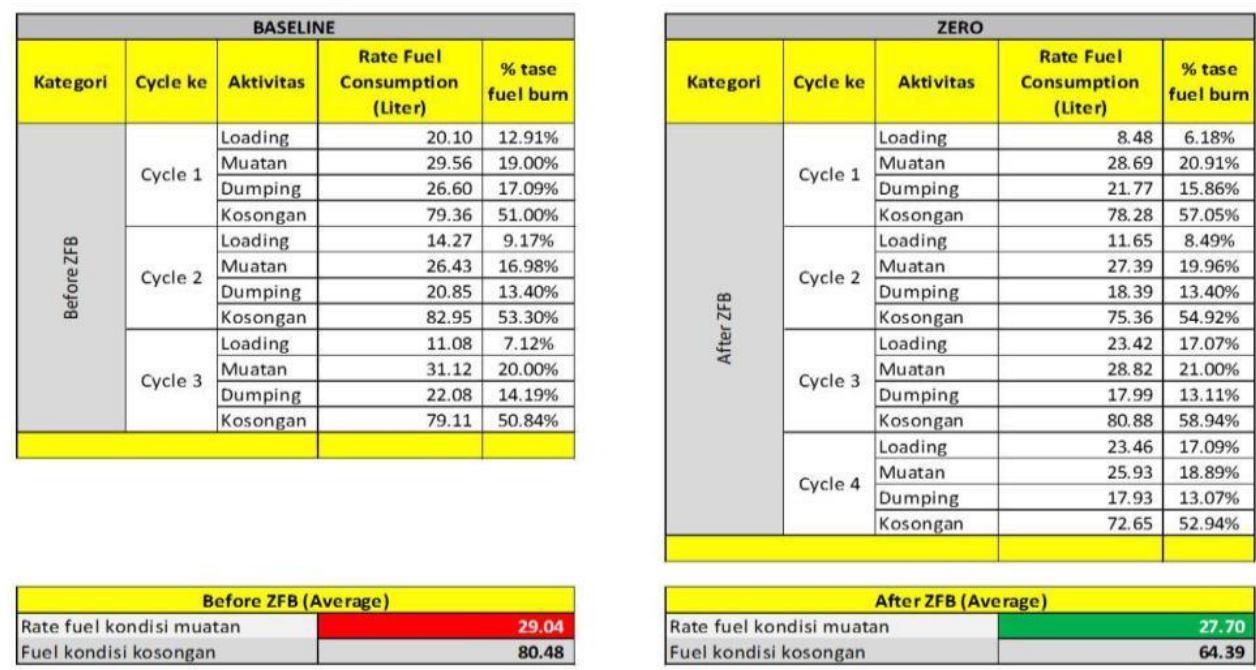

b. Pendekatan Akumulasi Jarak 
Perhitungan dilakukan dengan menyamakan jarak tempuh di data base line dan zero line, dimana aeuan yang digunakan adalah jarak tempuh terpendek.

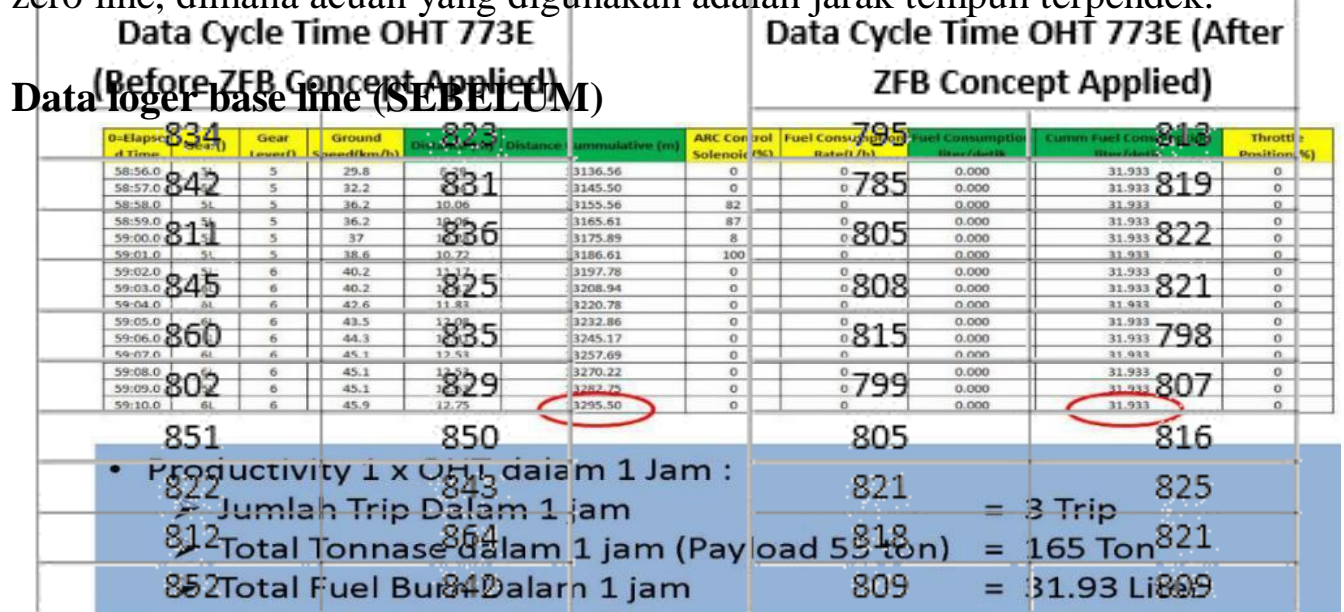

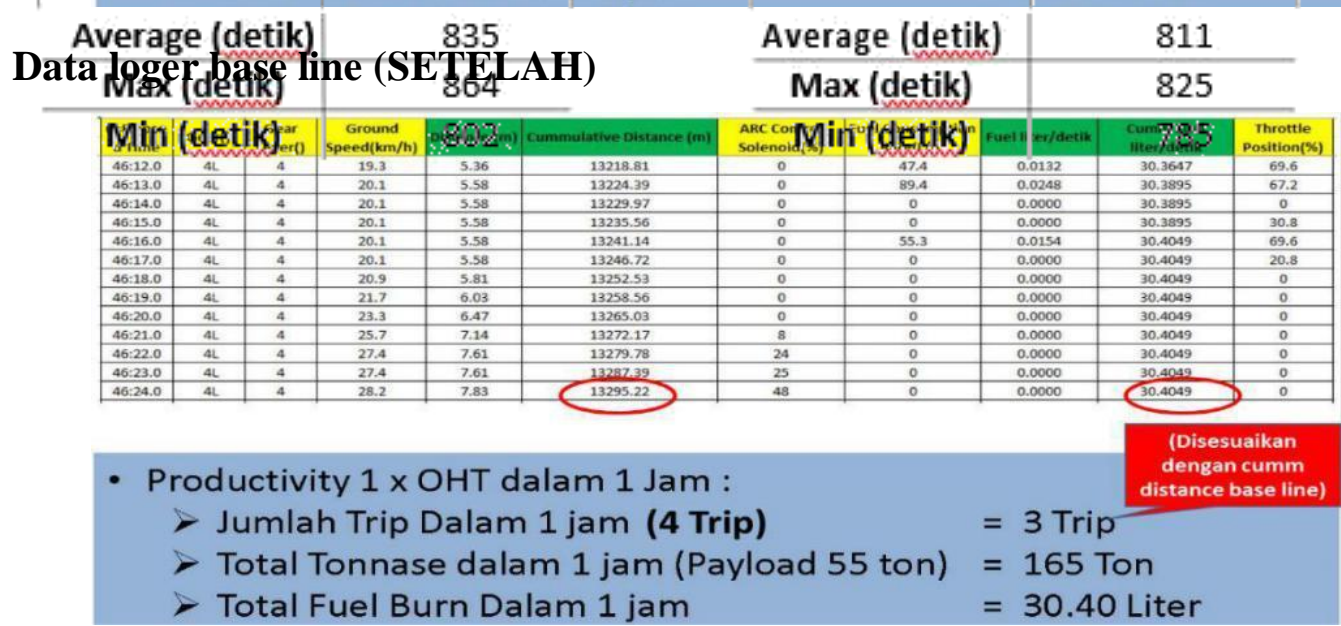

\section{5_Data Cycle Time Hauler}

Data cycle time hauler terdiri atas waktu loading, spotting, hauling, dumping dan return hauling. Berikut merupakan data cycle time rata-rata OHT 773E dengan loading point yang ada di pit barat dan dumping point di stockpile 6, total jarak tempuh yaitu $4.17 \mathrm{~km}$ (loading point to loading point). Kondisi di loading point dan dumping dibuat hampir sama pada saat pengambilan data sehingga perbedaan cycle time sebelum dan sesudah penerapan konsep Zero Fuel Burn itu murni dari efisiensi waktu saat OHT berada di jalur Zero Fuel Burn-nya. 
5.6_Data Physical Availability (PA) Alat

Berikut ini Data Down time alat OHT 773 selama 10 bulan (5 bulan sebelum penerapan ZFB dan 5

bulan setelah penerapan ZFB), khususnya terkait dengan data kerusakan di bagian tyre dan suspensi, sebagai berikut :

\begin{tabular}{|c|c|c|c|c|c|c|}
\hline \multirow{4}{*}{$\begin{array}{c}\text { Down Time Suspension } \\
\text { (hrs) }\end{array}$} & Oct-17 & Nov-17 & Dec-17 & Jan-18 & Feb-18 & Average \\
\cline { 2 - 8 } & 20.9 & 53.7 & 34.8 & 16.3 & 64.7 & 38.08 \\
\cline { 2 - 8 } & Mar-18 & Apr-18 & May-18 & Jun-18 & Jul-18 & Average \\
\cline { 2 - 8 } & 9.60 & 29.08 & 45.90 & 46.82 & 51.43 & 36.57 \\
\hline \multirow{4}{*}{ Down Time Tyre (hrs) } & Oct-17 & Nov-17 & Dec-17 & Jan-18 & Feb-18 & Average \\
\cline { 2 - 8 } & 57.88 & 40.80 & 67.60 & 29.80 & 25.50 & 44.32 \\
\cline { 2 - 8 } & Mar-18 & Apr-18 & May-18 & Jun-18 & Jul-18 & Average \\
\cline { 2 - 7 } & 23.90 & 13.30 & 28.70 & 21.80 & 29.20 & 23.38 \\
\hline
\end{tabular}

\section{PEMBAHASAN}




\section{1_Efisiensi Konsumsi Bahan Bakar/ Fuel Consumption}

a. Pendekatan Fuel Rate

\begin{tabular}{|l|l|c|}
\hline BASELINE & $\begin{array}{l}\text { RATE FUEL KONDISI MUATAN } \\
(\mathrm{L} / \mathrm{H})\end{array}$ & 29.04 \\
\hline ZERO & $\begin{array}{l}\text { RATE FUEL KONDISI MUATAN } \\
(\mathrm{L} / \mathrm{H})\end{array}$ & 27.70 \\
\hline \multicolumn{2}{|l}{ EFISIENSI FUEL } & $\mathbf{4 . 6 1 \%} \%$ \\
\hline
\end{tabular}

b. Pendekatan Akumulasi Jarak

\begin{tabular}{|c|c|c|c|}
\hline SIMULASI & SIKLUS & $\begin{array}{c}\text { AKUMULASI JARAK } \\
(\mathrm{M})\end{array}$ & $\begin{array}{c}\text { KONSUMSI BAHAN BAKAR } \\
(\mathrm{L} / \mathrm{H})\end{array}$ \\
\hline BASELINE & 3 & 13295.50 & 31.93 (Low Rate) \\
\hline ZERO & 3 & 13295.25 & 30.4 (Low Rate) \\
\hline \multicolumn{3}{|c}{ EFISIENSI FUEL } & 1.53 \\
\cline { 3 - 4 } & $\mathbf{4 . 7 9 \%}$ \\
\hline
\end{tabular}

\section{2_Peningkatan Produktivitas Unit Hauler}

Penggunaan gear dan kecepatan yang sesuai dengan Brake Performance Curve OHT $773 \mathrm{E}$, ternyata dapat mengurangi cycle time dari unit OHT tersebut sehingga menjadi lebih cepat, yang artinya ada peningkatan di sisi produktivitas alat. Berdasarkan pengambilan data aktual cycle time OHT, sebelum penerapan konsep Zero Fuel Burn cycle time OHT rata-rata sebesar 835 detik atau 13.9 menit sedangkan setelah penerapan konsep Zero Fuel Burn menjadi 811 detik atau 13.5 menit. Dengan menggunakan rumus berikut :

$$
\begin{aligned}
& \mathrm{P} \text { (before) }=\frac{H \cdot B D}{C}=\frac{23 \mathrm{bcm} .2 .13 \mathrm{ton} / \mathrm{bcm}}{(13.9 / 60) \mathrm{jam}}=211.4 \mathrm{ton} / \mathrm{jam} \\
& \mathrm{P}(\text { after })=\frac{H \cdot B D}{C}=\frac{23 \mathrm{bcm} \cdot 2.13 \mathrm{ton} / \mathrm{bcm}}{(13.5 / 60) \mathrm{jam}}=217.7 \mathrm{ton} / \mathrm{jam}
\end{aligned}
$$

Peningkatan Produktivitas $(\%)=\mathbf{2 1 7 , 7 - 2 1 1 , 4 = 6 , 3 t o n / j a m a t a u ~ 3 \% p e r u n i t ~ O H T ~}$ Besarnya peningkatan produktivitas per unit OHT setelah penerapan konsep Zero Fuel Burn yaitu sekitar 6.3 ton/jam/unit, dengan total unit OHT ada 10 buah maka dalam 1 jam terjadi peningkatan produksi sebesar 63 ton atau dalam sebulan sekitar 1,890 ton.

\section{3_Peningkatan Nilai PA Unit Hauler}




\section{a. Down time Suspension}

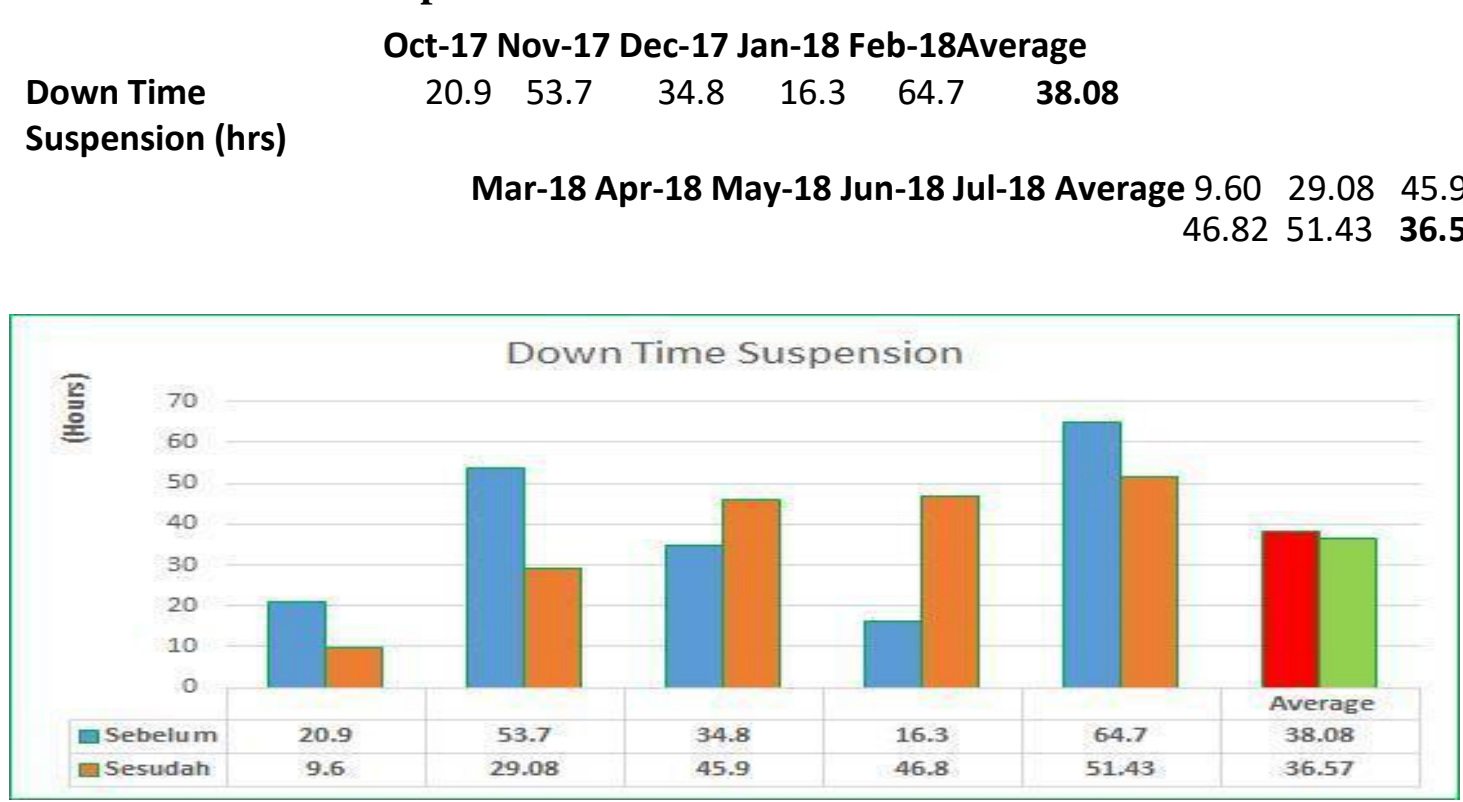

\section{Penurunan sebesar}

\section{$4.0 \%$}

b. Down time Tyre

Oct-17 Nov-17 Dec-17 Jan-18 Feb-18 Average

Down Time Tyre $\quad \begin{array}{llllll}57.88 & 40.80 & 67.60 & 29.80 & 25.50 & \mathbf{4 4 . 3 2}\end{array}$

(hrs)

Mar-18 Apr-18 May-18 Jun-18 Jul-18 Average

$\begin{array}{llllll}23.90 & 13.30 & 28.70 & 21.80 & 29.20 & 23.38\end{array}$ 


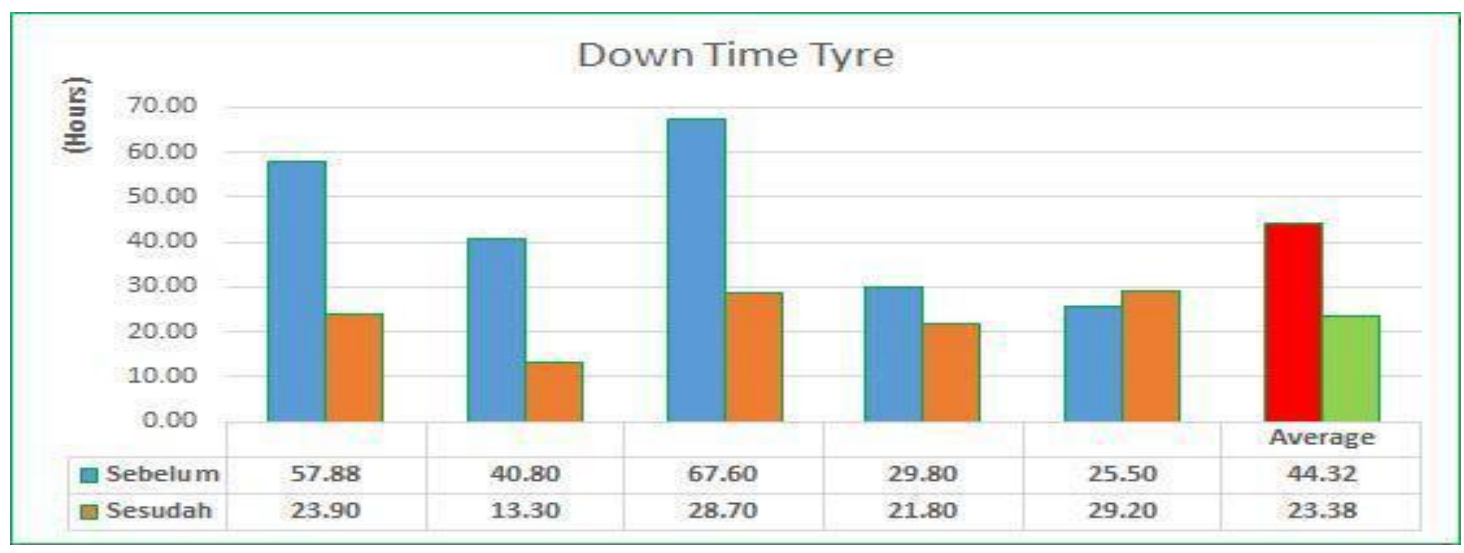

\section{Penurunan sebesar}

\section{$47.2 \%$}

\section{KESIMPULAN}

1. Konsep Zero Fuel Burn dapat diterapkan dengan membuat desain final jalan hauling yang memiliki grade sekitar 9 - 10\% pada kondisi turunan (downhill).

2. Efisiensi fuel consumption pada unit OHT sebesar $4.7 \%$.

3. Dengan menerapkan konsep Zero Fuel Burn, produktivitas unit hauler ternyata juga dapat meningkat sebesar 3\% per jam per unitnya, karena menggunakan gear dan kecepatan yang optimum pada saat di jalur downhill sehingga cycle time OHT menjadi lebih cepat.

4. Dengan menerapkan konsep Zero Fuel Burn dan Excelent Traffic Operation pada jalan hauling, maka Down Time unit OHT selama 5 Bulan untuk bagian tyre menurun $\mathbf{4 7 . 2} \%$ dan suspensi menurun $4 \%$.

\section{DAFTAR PUSTAKA}

- Caterpillar handbook Edition 43.

- Sucofindo-perencanaan geometri jalan tambang.

- Sulistianto, Prof. Dr. Ir. M.T. Budi. 2013. Diktat Kuliah Peralatan Tambang. Bandung : ITB. 